\title{
PENERAPAN KEGIATAN MENDONGENG DALAM MENINGKATKAN SIKAP TOLERANSI PADA ANAK USIA 5-6 TAHUN DI TK ABA MELATI
}

\author{
Susi Ratnawati \\ Surel : susiratnawati@gmail.com
}

\begin{abstract}
ABSTRAK
Penelitian ini bertujuan untuk meningkatkan sikap toleransi pada anak. Subjek penelitian adalah anak usia 5-6 tahun kelompok B2 TK ABA Melati yang berjumlah 23 orang. Dari 23 orang anak, anak yang memperoleh kriteria berkembang sesuai harapan sebanyak 7 orang anak $(30 \%)$, dan anak yang memperoleh kriteria mulai berkembang sebanyak 16 orang anak (70\%). Nilai rata-rata sikap tolernasi anak yaitu 54,11. Hasil analisa setelah diberikan tindakan I yaitu diperoleh sikap toleransi anak masih mulai berkembang. Hasil analisa pada siklus II terjadi peningkatan yang signifikan, anak yang memperoleh kriteria berkembang sangat baik sebanyak 14 orang anak (61\%), anak yang memperoleh kriteria berkembang sesuai harapan sebanyak 5 orang anak (22\%), dan anak yang memperoleh kriteria mulai berkembang sebanyak 4 orang anak (17\%). Nilai ratarata sikap toleransi anak yaitu 81,17. Pada siklus ini kemampuan klasikal anak sudah tercapai yaitu sebesar $83 \%$.
\end{abstract}

Kata Kunci : Kegiatan Mendongeng, Sikap Toleransi

\section{PENDAHULUAN}

Salah satu bagian terpenting yang harus mendapatkan perhatian terkait dengan pendidikan yang diberikan sejak usia dini adalah pendidikan karakter. Pendidikan karakter bagi anak usia dini dimaksudkan agar anak dapat mengetahui dan menanamkan nilainilai kebaikan dalam dirinya, sehingga anak dapat menjadi pribadi yang memiliki jiwa toleransi yang tinggi terhadap segala perbedaan yang terjadi di masyarakat.

Louis dalam Saifudin (2011:4) menyatakan sikap adalah suatu bentuk evaluasi atau reaksi perasaan seseorang yang mendukung maupun perasaan tidak mendukung terhadap suatu objek". Sementara itu Fadlillah \& Khorida (2013:191) toleransi adalah sikap atau tindakan yang menghargai perbedaan agama, suku, etnis, dan pendapat orang lain yang berbeda dari dirinya. Berdasarkan pengertian sikap dan toleransi yang telah diuraikan di atas, dapat disimpulkan bahwa pengertian sikap toleransi adalah kecenderungan perilaku atau arah perilaku yang dapat mendorong seseorang untuk membedakan perbuatan baik dan buruk, menunjukan perilaku sopan santun, member contoh kegiatan ritual hari besar agama, dan berperilaku baik terhadap orang lain.

Adapun ciri-ciri sikap toleransi yang telah diuraikan dalam Kamus Besar Bahasa Indonesia, yaitu: 1) saling menghormati (sikap, pendapat, dan saran) orang lain, 2) saling menghargai, 3) menerima 
perbedaan, 4) saling membantu, 5) menghindari konflik dan perpecahan dalam kehidupan, 6) tidak sombong,7) tidak egois, 8) tidak memaksakan kehendak, 9) tidak pernah meremehkan orang lain. Jika dilihat dalam Peraturan Menteri

Pendidikan Nasional Republik Indonesia nomor 58 Tahun 2009 Tentang Standart PAUD menyatakan beberapa tingkat pencapaian perkembangan nilai moral dan agama anak usia 5-6 tahun, yaitu: a). membedakan perilaku baik dan buruk, b) memahami perilaku sopan santun dan hormat, c). mengenal ritual dan hari besar agama lain, d). menunjukkan perilaku baik terhadap orang lain.

Berdasarkan pengalaman peneliti sebagai guru TK ABA Melati J1. Nuri XIII No. 500-A Perumnas Medan II pada kelompok B2 yang rata-rata berusia 5-6 tahun, peneliti melihat bahwa sikap toleransi anak belum sesuai dengan tingkat pencapaian perkembangan yang tertulis dalam Peraturan Menteri Pendidikan Nasional nomor 58 tentang standar pendidikan anak usia dini. Seperti, mengejek teman yang secara fisik (gemuk, kurus, hitam, dan lain-lain), tidak menghormati guru, tidak mensyukuri nikmat, anak tidak mau meminjamkan alat tulis kepada teman, tidak mau berbagi mainan kepada teman, beberapa anak lebih memilih anak tertentu untuk dijadikan teman satu kelompok dan menolak berteman dengan anak yang tidak disukainya, anak tidak mau belajar dan mengganggu temannya yang sedang belajar, menertawakan teman yang terjatuh tanpa mau menolongnya.

Sikap toleransi anak belum sesuai dengan tingkat pencapaian perkembangan nilai moral dan agama anak usia 5-6 yang dituliskan dalam Permendiknas 58, hal ini dikarenakan guru belum mengajak anak untuk membuat kesepakatan tentang bersikap terhadap teman, seharusnya guru mengajak anak membuat kesepakatan tentang sikap toleransi, seperti kesepakatan untuk tidak menganggu temannya dan tidak mengejek teman. Jika dilanggar maka anak mendapat sanksi yaitu mengakui kesalahannya di depan kelas dan mengutip sampah yang ada di dalam kelas.

Anak belum mendapatkan pendidikan karakter secara maksimal di kelas, dimana seharusnya guru dapat menyeimbangkan antara pembelajaran kognitif dengan pembelajaran karakter yang diberikan kepada anak, khususnya sikap toleransi. Anak kurang tertarik dalam mengenal sikap toleransi karena pemahaman mengenai sikap toleransi belum maksimal diberikan kepada anak, seharusnya guru dapat lebih memvariasikan metode yang digunakan dalam mengembangkan sikap toleransi anak usia dini, seperti dengan kegiatan mendongeng sehingga anak menjadi lebih tertarik 
dalam menunjukkan sikap toleransinya di kehidupan sehari-hari.

Mendongeng merupakan salah satu kegiatan yang dapat digunakan dalam mengembangkan sikap toleransi pada anak usia dini, hal ini sesuai yang dinyatakan oleh Mursini (2011:78) "mendongeng adalah salah satu cara menguatkan karakter anak". Para orangtua dan Pendidik memiliki kewajiban untuk menggiatkan kembali tradisi mendongeng yang mulai jarang diberikan oleh para orangtua di rumah dan para pendidik di sekolah. Dunia dongeng merupakan dunia yang menakjubkan

terutama bagi anak-anak.Lewat sebuah dongeng sebuah komunikasi dan kedekatan emosional dapat tercapai. Transfer nilai-nilai yang terkandung dalam sebuah dongeng dapat lebih mudah dimengerti oleh anak.

Hal terpenting dalam mendongeng untuk anak bukanlah lamanya waktu mendongeng, tetapi kualitas dan kuantitasnya. Adapun durasi untuk mendongeng pada anak menurut Jasmin (2011:53-54) yaitu:

a. Usia 1-4 tahun, untuk anak usia 1-4 tahun waktu yang diperlukan dalam menceritakan dongeng adalah sekitar 5-7 menit. Lebih dari itu konsentrasinya akan buyar dan anak akan mengalihkan perhatiannya pada hal lain. Maksimal tokoh yang ditampilkan hanya dua tokoh,

b. Usia 4-8 tahun waktu yang diperlukan dalam menceritakan dongeng adalah 10-15 menit.

Maksimal tokoh yang ditampilkan dalam cerita adalah empat tokoh,

c. Usia 8-12 tahun, untuk anak usia 8-12 tahun waktu mendongeng yang diperlukan adalah sekitar 25 menit.

Berdasarkan latar belakang masalah, dapat dikaji ada beberapa permasalahan yang dirumuskan sebagai berikut:Apakah kegiatan mendongeng dapat meningkatkan sikap toleransi anak usia 5-6 tahun di TK ABA Melati Tahun Ajaran 2015/2016?

Sesuai dengan perumusan masalah diatas maka yang menjadi tujuan yang ingin dicapai dalam

penelitian ini adalah: untuk mengetahui kegiatan mendongeng dapat meningkatkan sikap toleransi anak usia 5-6 tahun di TK ABA Melati Tahun Ajaran 2015/2016.

\section{METODE PENELITIAN}

Penelitian ini dilakukan di TK ABA Melati Medan Tahun Ajaran 2015/2016, beralamat di Jl. Nuri XIII No. 500-A Perumnas Medan II dan waktu penelitian dilaksanakan selama 4 Bulan (Maret 2016 s/d Juni 2016).

Subjek penelitian ini adalah seluruh anak usia 5-6 tahun kelompok B2 di TK ABA Melati Medan Tahun Ajaran 2015/2016 yang berjumlah 23 orang, yang terdiri dari 13 orang anak laki-laki dan 10 orang anak perempuan. Objek dari penelitian ini adalah penggunaan kegiatan 
mendongeng dalam meningkatkan sikap toleransi anak.

Teknik yang digunakan untuk pengumpulan data dalam penelitian ini adalah tes unjuk kerja/kemampuan (performance test) sesuai dengan kisikisi yang dikembangkan peneliti seperti dalam tabel berikut :

Tabel Kisi-kisi Pedoman Observasi Sikap Toleransi Pada Anak Usia Dini

\begin{tabular}{|c|c|c|}
\hline No & Indikator & Deskriptor \\
\hline 1. & $\begin{array}{l}\text { Membedakan } \\
\text { perbuatan baik dan } \\
\text { buruk. }\end{array}$ & $\begin{array}{ll}\text { 1. } & \text { dapat } \\
\text { menentukan } \\
\text { tokoh yang } \\
\text { memiliki sikap } \\
\text { toleransi dan } \\
\text { tokoh yang } \\
\text { tidak memiliki } \\
\text { sikap toleransi } \\
\text { 2. } \text { melakukan } \\
\text { aktivitas } \\
\text { bersama } \\
\text { dengan semua } \\
\text { teman } \\
\text { menerima } \\
\text { konsekuensi } \\
\text { atas perbuatan } \\
\text { yang } \\
\text { dilakukan }\end{array}$ \\
\hline 2. & $\begin{array}{l}\text { Menunjukkan } \\
\text { perilaku mulia } \\
\text { (sopan- } \\
\text { santun,hormat). }\end{array}$ & $\begin{array}{ll}\text { 1. } & \text { membantu } \\
& \text { teman yang } \\
& \text { sedang } \\
& \text { kesulitan } \\
\text { 2. } & \text { mendengarkan } \\
& \text { dan } \\
& \text { melaksanakan } \\
& \text { perintah guru } \\
\text { 3. } & \text { meminta maaf } \\
& \text { kepada teman }\end{array}$ \\
\hline 3. & $\begin{array}{l}\text { Perilaku baik } \\
\text { berhubungan dengan } \\
\text { orang lain. }\end{array}$ & 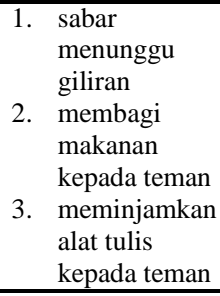 \\
\hline
\end{tabular}

Penelitian ini menggunakan desain model Arikunto (2008:16). Penelitian ini direncanakan dengan 2 siklus, yakni siklus I dan siklus II, yang terdiri dari empat komponen yaitu: 1. Perencanaan, 2. Pelaksanaan, 3. Pengamatan, 4. Refleksi.

Data hasil penelitian yang dikumpulkan dianalisis dengan menggunakan teknik deskriptif menggunakan rumus:

$$
P=\frac{f}{n} \times 100 \%
$$

Dimana :

$\mathrm{P}=$ Angka persentase klasikal

$\mathrm{f}=$ Jumlah anak yang mengalami

perubahan

$\mathrm{n}=$ Jumlah anak seluruhnya.

Setelah rumus untuk mencari perkembangan individu dilakukan, maka selanjutnya adalah mencari perkembangan rata-rata anak dengan menggunakan rumus :

$$
={ }_{\Sigma} \Sigma(\text { Aqib, 2011:16) }
$$

Keterangan :

$\mathrm{x}=$ Nilai rata-rata

$\sum \mathrm{x}=$ Jumlah semua nilai anak

$\sum \mathrm{n}=$ Jumlah anak

Selanjutnya untuk mengetahui persentase peningkatan sikap toleransipada anak secara keseluruhan atau klasikal, maka digunakan rumus :

$$
-\mathrm{X} 100 \%
$$

$\mathrm{P}=$ persentase peningkatan sikap toleransi pada anak.

$\mathrm{f}=$ jumlah subjek yang mengalami perubahan.

$\mathrm{n}=$ jumlah subjek keseluruhan

Kriteria penilaian yang digunakan ialah: 
Tabel kriteria penilaian

\begin{tabular}{|c|c|}
\hline Prestasi & Keterangan \\
\hline $80 \%-100 \%$ & Berkembang Sangat Baik \\
& (BSB) \\
$60 \%-79 \%$ & Berkembang Sesuai \\
& Harapan (BSH) \\
$30 \%-59 \%$ & Mulai Berkembang (MB) \\
$10 \%-29 \%$ & Belum Berkembang (BB) \\
\hline
\end{tabular}

Adaptasi : Aqib (2011:41) dan Permen No. 58 Tahun 2009

Dikatakan mengalami peningkatan sikap toleransi anak apabila terdapat $75 \%$ anak telah berkembang sesuai harapan.

\section{HASIL DAN PEMBAHASAN}

Pada tahap perencanaan, peneliti merencanakan teknis pelaksanaan penelitian tindakan kelas. Setelah menyusun perencanaan, selanjutnya peneliti melakukan pembelajaran yang akan diterapkan yaitu kegiatan mendongeng.

Selama proses pembelajaran berlangsung, observer mengamati dan mengisi lembar observasi yang telah disediakan peneliti. Selanjutnya paparan gambaran awal setelah dilakukannya tindakan dan keadaan pada siklus I yang diperoleh dari hasil observasi dapat dilihat pada tabel di bawah ini:

Table Keadaan Peningkatan Sikap Toleransi Anak Pada Siklus 1

\begin{tabular}{|c|c|c|c|}
\hline \multirow{2}{*}{$\begin{array}{c}\text { Kode } \\
\text { Anak }\end{array}$} & \multicolumn{2}{|c|}{ Pertemuan II } & \multirow{2}{*}{ Keterangan } \\
\cline { 2 - 3 } & $\begin{array}{c}\text { Jumlah } \\
\text { Skor }\end{array}$ & Nilai & \\
\hline 1 & 5 & 55,6 & MB \\
\hline 2 & 4 & 44,4 & MB \\
\hline 3 & 5 & 55,6 & MB \\
\hline
\end{tabular}

\begin{tabular}{|c|c|c|c|}
\hline 4 & 6 & 66,7 & BSH \\
\hline 5 & 6 & 66,7 & $\overline{\mathrm{BSH}}$ \\
\hline 6 & 5 & 55,6 & MB \\
\hline 7 & 6 & 66,7 & $\overline{\mathrm{BSH}}$ \\
\hline 8 & 4 & 44,4 & MB \\
\hline 9 & 5 & 55,6 & $\mathrm{MB}$ \\
\hline 10 & 7 & 77,8 & $\overline{\mathrm{BSH}}$ \\
\hline 11 & 3 & 33,3 & MB \\
\hline 12 & 3 & 33,3 & MB \\
\hline 13 & 5 & 55,6 & MB \\
\hline 14 & 6 & 66,7 & BSH \\
\hline 15 & 7 & 77,8 & $\overline{\mathrm{BSH}}$ \\
\hline 16 & 6 & 66,7 & BSH \\
\hline 17 & 4 & 44,4 & $\mathrm{MB}$ \\
\hline 18 & 4 & 44,4 & $\mathrm{MB}$ \\
\hline 19 & 5 & 55,6 & MB \\
\hline 20 & 4 & 44,4 & MB \\
\hline 21 & 5 & 55,6 & MB \\
\hline 22 & 4 & 44,4 & MB \\
\hline 23 & 3 & 33,3 & MB \\
\hline \multicolumn{2}{|r|}{ Jumlah } & 1244,6 & \\
\hline \multicolumn{2}{|r|}{$\begin{array}{l}\text { Rata- } \\
\text { Rata }\end{array}$} & 54,11 & \\
\hline
\end{tabular}

Berdasarkan hasil pengamatan pada Siklus I Pertemuan II, peneliti melihat bahwa peningkatan kreativitas anak belum meningkat dan masih cenderung rendah. Tabel di atas menunjukkan bahwa pada siklus I, peningkatan kreativitas anak sebagai berikut: $20 \%$ tergolong sangat baik, $47 \%$ tergolong baik, dan 33\% tergolong cukup baik.

Berdasarkan hasil pengamatan hingga pertemuan kedua pada siklus I selama proses tindakan kegiatan mendongeng dilakukan, diperoleh bahwa sikap toleransi pada anak kurang maksimal dalam kegiatan mendongeng, hal ini terlihat dari hasil skor test performance yang belum sesuai dengan apa yang ditetapkan dalam kriteria keberhasilan sikap toleransi pada anak usia dini. Hal ini dikarenakan, pada saat kegiatan mendongeng siklus I dilaksanakan masih terdapat beberapa anak yang tidak fokus mendengarkan cerita 
dongeng seperti imajinasi anak tidak berkembang, berbicara kepada teman, menganggu temannya dan bergerak dari tempat duduknya. Mimik wajah dan intonasi suara peneliti juga masih kurang maksimal dalam menyampaikan isi cerita dongeng kepada anak sehingga anak menjadi kurang tertarik untuk mendengarkan cerita dongeng. Maka dari itu, sangat diperlukan perbaikan kegiatan mendongeng di siklus II agar kriteria keberhasilan sikap toleransi anak usia dini dapat tercapai. Pada kegiatan mendongeng siklus II peneliti menggunakan benda-benda kongkrit seperti boneka tangan serta setting ruangan diubah menjadi di luar kelas agar anak dapat lebih mudah berimajinasi dan menerima pesan yang ingin disampaikan guru melalui cerita dongeng, dengan harapan kriteria keberhasilan sikap toleransi anak dapat tercapai.

Pada tahap perencanaan ini, ada beberapa hal perbaikan yang dilakukan oleh peneliti, yaitu: 1) Menentukan tema yang akan diajarkan sesuai silabus dan kurikulum. 2) Menyusun rencana pembelajaran dalam bentuk Rencana
Kegiatan Harian (RKH). 3) Mempersiapkan bahan dan peralatan yang akan digunakan dalam kegiatan mendongeng, 4) kegiatan mendongeng dilaksanakan di luar kelas agar anak lebih leluasa dan bersemnagat dalam mendengarkan cerita, 5) Mendongeng dengan boneka tangan, 6) Mempersiapkan lembar pedoman wawancara tentang peningkatan karakter toleransi anak dan lembar pedoman observasi untuk mendongeng.

Pada tahap ini kegiatan yang dilaksanakan adalah melaksanakan kegiatan berupa perbaikan siklus I yang telah direncanakan. Jika pada tindakan siklus I, peneliti menggunakan buku bergambar dalam mendongeng, pada siklus II peneliti menggunakan boneka tangan dalam mendongeng. Pada siklus I kegiatan mendongeng dilaksanakan di dalam kelas, maka pada siklus II dilaksanakan di luar kelas (halaman sekolah). Cerita dongeng pada siklus I dan siklus II juga berbeda. Pelaksanaan siklus II berlangsung sebanyak dua kali pertemuan.

Tabel Keadaan Peningkatan Sikap Toleransi Anak Pada Siklus II

\begin{tabular}{|c|c|c|c|}
\hline \multirow{2}{*}{$\begin{array}{l}\text { Kode } \\
\text { Anak }\end{array}$} & \multicolumn{2}{|c|}{ Pertemuan II } & \multirow{2}{*}{ Keterangan } \\
\hline & $\begin{array}{l}\text { Jumlah } \\
\text { Skor }\end{array}$ & Nilai & \\
\hline 1 & 8 & 88,9 & BSB \\
\hline 2 & 8 & 88,9 & $\mathrm{BSB}$ \\
\hline 3 & 9 & 100 & BSB \\
\hline 4 & 8 & 88,9 & BSB \\
\hline 5 & 8 & 88,9 & $\mathrm{BSB}$ \\
\hline 6 & 8 & 88,9 & $\mathrm{BSB}$ \\
\hline 7 & 8 & 88,9 & BSB \\
\hline 8 & 7 & 77,8 & $\overline{\mathrm{BSH}}$ \\
\hline 9 & 8 & 88,9 & BSB \\
\hline 10 & 9 & 100 & $\mathrm{BSB}$ \\
\hline 11 & 7 & 77,8 & $\mathrm{BSH}$ \\
\hline 12 & 5 & 55,6 & MB \\
\hline 13 & 8 & 88,9 & $\mathrm{BSB}$ \\
\hline 14 & 8 & 88,9 & $\mathrm{BSB}$ \\
\hline 15 & 9 & 100 & BSB \\
\hline 16 & 9 & 100 & BSB \\
\hline 17 & 5 & 55,6 & MB \\
\hline 18 & 6 & 66,7 & $\mathrm{BSH}$ \\
\hline 19 & 5 & 55,6 & MB \\
\hline 20 & 6 & 66,7 & $\mathrm{BSH}$ \\
\hline 21 & 8 & 88,9 & $\mathrm{BSB}$ \\
\hline 22 & 6 & 66,7 & $\mathrm{BSH}$ \\
\hline 23 & 5 & 55,6 & MB \\
\hline \multicolumn{2}{|c|}{ Jumlah } & 1867,1 & \\
\hline \multicolumn{2}{|c|}{ Rata-Rata } & 81,17 & \\
\hline
\end{tabular}


Berdasarkan hasil siklus II
yang dilakukan peneliti sikap toleransi anak mengalami kemajuan. Dengan demikian, pada siklus II

kegiatan pembelajaran yang dilakukan dipandang sudah cukup dan tidak perlu dilanjutkan pada siklus berikutnya. Selama tindakan pada siklus II sikap toleransi tergolong berkembang sangat baik, dimana mayoritas anak telah memiliki sikap toleransi. Untuk itu pada siklus II sangat terdapat peningkatan sikap

toleransi pada anak. Dengan mendengarkan dongeng anak dapat

mengetahui pesan-pesan yang terkandung diidalamnya tentang sikap toleransi. Dengan mengajak anak membahas setiap tokoh, menceritakan kembali cerita dongeng, dan mengajak anak untuk berinteraksi langsung memainkan boneka tangan dan terbukti keseluruhan anak mengikuti kegiatan dengan baik sesuai kesepakatan dan langkahlangkah kegiatan mendongeng.

Berdasarkan data temuan penelitian siklus I dan siklus II

menunjukkan adanya kemajuan perolehan skor kriteria keberhasilan sikap toleransi pada anak, bahwa kegiatan mendongeng yang dilakukan di siklus II dengan mengunakan benda kongkrit (boneka tangan) serta ruangan yang lebih luas dan lapang mampu membuat anak berimajinasi dan dapat menerima isi pesan yang ingin disampaikan oleh peneliti melalui isi cerita dongeng yang telah dibacakan. Kegiatan mendongeng di
Siklus II terbukti efektif serta berdampak positif terhadap sikap toleransi pada anak usia dini. Suasana belajar yang tercipta lebih menyenangkan karena anak belajar sambil bermain, mereka belajar dengan baik dengan kegiatan yang direncanakan. Penggunaan kegiatan mendongeng dapat meningkatkan sikap toleransi pada anak. Hal ini dapat terlihat dari persentase sikap toleransi pada anak, seperti membedakan perbuatan baik dan buruk, memahami perilaku mulia (penolong, sopan, hormat, dsb), serta menunjukkan sikap toleransi. Pada siklus I terlihat dari tabel 3 dapat dilihat bahwa nilai rata-rata anak

54,11, yang berarti rata-rata peningkatan sikap toleransi anak pada kriteria mulai berkembang. pada gambar 4.1 diperoleh bahwa anak yang memperoleh kriteria berkembang sesuai harapan sebanyak 7 orang anak (30\%), dan anak yang memperoleh kriteria mulai berkembang sebanyak 16 orang anak (70\%).

Sementara itu terjadi peningkatan pada siklus II, hal ini berdasarkan tabel 4 bahwa setelah dilakukan tindakan pada Siklus II diperoleh nilai rata-rata anak 81,17 yang berarti rata-rata peningkatan sikap toleransi anak pada kriteria berkembang sangat baik. Pada gambar 4.2 terlihat bahwa anak yang memperoleh kriteria berkembang sangat baik sebanyak 14 orang anak (61\%), anak yang memperoleh 
kriteria berkembang sesuai harapan sebanyak 5 orang anak (22\%), dan anak yang memperoleh kriteria mulai berkembang sebanyak 4 orang anak (17\%). Nilai rata-rata sikap toleransi anak juga mengalami peningkatan dimana pada keadaan siklus I diperoleh rata-rata sikap toleransi anak 54,11 sedangkan setelah dilakukan tindakan pada Siklus II, maka sikap toleransi anak menjadi 81,17. Hal ini berarti terjadi peningkatan sikap toleransi anak sebesar 27,06.

Kegiatan mendongeng dapat meningkatkan sikap toleransi pada anak karena melalui kegiatan

mendongeng, anak diajak
mendengarkan dongeng yang bertemakan tentang sikap toleransi, anak akan mengetahui tokoh-tokoh karakter orang yang bersikap baik dan yang tidak, dampak dari orang yang tidak bersikap toleransi. Dari gambar 4.3 dapat dilihat pada kriteria berkembang sangat baik terjadi peningkatan yang signifikan dari Siklus I ke Siklus II menjadi 14 orang anak, dari yang sebelumnya berjumlah 0 orang anak, berarti terjadi penambahan sebanyak 14 orang anak. Sedangkan pada kriteria

berkembang sesuai harapan mengalami penurunan dari 7 anak menjadi 5 orang anak, pada kriteria mulai berkembang mengalami penurunan dari 16 orang anak menjadi 4 orang anak.Serta dalam kegiatan mendongeng, anak diajak untuk berinteraksi mempraktekkan langsung kegiatan mendongeng dengan teman-temannya. Hal ini melatih anak agar dapat bersosialisasi dengan semua teman-temannya dan memberikan pengalaman yang menarik buat anak.

Dengan demikian berdasarkan penelitian tindakan kelas yang dilakukan telah terbukti bahwasannya kegiatan mendongeng merupakan strategi yang tepat untuk meningkatkan sikap toleransi pada anak usia 5-6 tahun di TK ABA Melati Medan Tahun Ajaran 2015/2016 yang beralamat di Jl. Nuri XIII No. 500-A Perumnas Medan II.

\section{SIMPULAN}

Berdasarkan pembahasan hasil penelitian yang telah dilaksanakan, maka dapat diperoleh kesimpulan bahwa dengan kegiatan mendongeng dapat meningkatkan sikap toleransi pada anak usia 5-6 tahun di TK ABA Melati Medan Tahun Ajaran 2015/2016 yang beralamat di Jl. Nuri XIII No. 500-A Perumnas Medan II, yaitu :

a. Kegiatan mendongeng dapat meningkatkan sikap tolernasi anak usia 5-6 tahun di TK ABA Melati Medan. Peningkatan sikap toleransi anak pada siklus I diperoleh : dari 23 orang anak, anak yang memperoleh kriteria berkembang sesuai harapan sebanyak 7 orang anak (30\%), dan anak yang memperoleh kriteria mulai berkembang sebanyak 16 orang anak $(70 \%)$. 
Nilai rata-rata sikap tolernasi anak yaitu 54,11.

b. Pada siklus II terjadi peningkatan yang signifikan, anak yang memperoleh kriteria berkembang sangat baik sebanyak 14 orang anak (61\%), anak yang memperoleh kriteria berkembang sesuai harapan sebanyak 5 orang anak (22\%), dan anak yang

memperoleh kriteria mulai berkembang sebanyak 4 orang anak (17\%). Nilai rata-rata sikap toleransi anak yaitu 81,17. Pada siklus ini kemampuan klasikal anak sudah tercapai yaitu sebesar $83 \%$.

\section{DAFTAR RUJUKAN}

Aqib. Zainal. 2011. Penelitian Tindakan Kelas. Bandung: Yrama Widya.

Arikunto, dkk. 2008. Penelitian Tindakan Kelas. Jakarta: Bumi Aksara.

Fadlillah, M \& Khorida, L.M. 2013. Pendidikan Karakter Anak Usia Dini Konsedan Aplikasinya Dalam Paud. Yogjakarta:Ar-Ruzz Media.

Jasmin. 2013. Terapi Kecerdasan Anak Dengan Dongeng. Yogyakarta : Berlian Media.

Mursini. 2011. Apresiasi \& Pembelajaran Sastra Anakanak. Bandung: Cipta Pustaka.
Peraturan Menteri Pendidikan Nasional Republik Indonesia Nomor 58. 2009. Standart Pendidikan Anak Usia Dini. Jakarta: DEPDIKNAS.

Saifuddin, M.A.2011. Sikap Manusia Teori dan Pengukurannya. Yogyakarta : Pustaka Pelajar.

Susi Ratnawati. 2016. Peningkatan Sikap Toleransi Pada Anak Usia 5-6 Tahun Melalui Kegiatan Mendongeng Di TK ABA Melati Tahun Ajaran 2015/2016. Medan. 
